\title{
Convocatoria y suscripción
}





\section{Convocatoria}

Se convoca a participar mediante trabajos originales e inéditos y que no estén postulando en otras revistas u órganos editoriales 1 la Revista Derecho Global. Estudios Sobre Derecho y Justicia. Es una publicación en formato rustico y electrónico cuatrimestral, de la División de Estudios Jurídicos del Centro Universitario de Ciencias Sociales y Humanidades de la Universidad de Guadalajara con números de registro internacional ISSN 2448-5128 e ISSNE 2448-5136 se edita el primer día de marzo, julio y noviembre.

Los trabajos deberán ser resultado de la investigación ya sea local, Estatal, Nacional o Internacional en el ámbito del Derecho, de la Justicia y de las ciencias sociales afines a éstas.

\section{Normas de presentación de artículos}

a) Los artículos originales e inéditos en idiomas español, inglés y francés ya terminados deben ser enviados en formato word al correo de la revista: derechoglobal@csh.udg.mx

b) El artículo no debe contener el nombre del autor o autores, que permita su identificación en el texto principal.

c) El autor o autores conservarán una copia idéntica de la información enviada.

d) El autor o autores, en una hoja por separado agregarán el nombre, así como una ficha biográfica. Verificando su recepción con el acuse de recibo.

e) Deberán enviar en un documento por separado, una biografía breve de cada uno de los autores, que no exceda de 150 palabras, con los grados académicos e institución donde los obtuvieron, datos principales de actividad de investigación y cargo que desempeña, institución, dirección electrónica, dirección postal, teléfono, ciudad, país.

f) El título del artículo se recibirá en español e inglés.

g) El texto deberá estar escrito en formato Word, en letra Times New Roman, tamaño 12 puntos, 1.5 de interlínea, tamaño carta, numeradas en el margen 
superior derecho, con una extensión mínima de 6,000 y una máxima de 8,000 palabras que equivale de 15 a 20 páginas, con un formato normal de 2.5 centímetros para el margen inferior y superior y 3.0 centímetros para los márgenes izquierdo y derecho.

h) Es necesario separar el artículo para una mejor comprensión en subtítulos y si los hubiera en incisos y sub incisos, alineados a la izquierda.

i) Las notas a pie de página deberán ser marcadas dentro de texto con un número realzado arábigo y anotando a pie de página, tama ño de 10 e interlineado de 1.15, con el modelo APA, la información correspondiente al contenido de la fuente consultada separando cada uno de los elementos de que se compone la información con una coma, iniciando por los apellidos del autor, título, editorial, lugar de impresión, páginas, etc.

j) En el caso de notas de internet es necesario agregar además de los datos de la cita, autor y título, En caso de llevar cuadros, ilustraciones, gráficas, se identificarán con un número ascendente y agregándolos por separado en archivo preferentemente Excel o Word e indicando en el texto general el lugar de cada elemento.

k) Cuando se citen fragmentos de obras en otra lengua, el autor deberá ofrecer a pie de página una traducción al español propia y especificar que se trata de una. Si se ofrece una traducción de un autor distinto del que suscribe, se le deberá dar el crédito, tanto en la cita como en la bibliografía.

Conforme al estilo APA, salvo la abreviatura latina et al., ni su forma destrabada ibídem; por lo cual, cada que se repita una referencia deberá volver a citarse no utilizar su forma destrabada ibídem. Tampoco, $c f$. ni $c f r$., sino la forma castellana véase.

1) Forma de redactar la Bibliografía:

Libros:

Apellidos, A. A. (Año). Título. Lugar: Editorial. 
Capítulo de libro:

Apellidos, A. A. (Año). Título del capítulo o entrada, en A. Editor, y B. Editor (eds./comps.), Título del libro (pp. xxx-xxx). Lugar: Editorial.

Artículo en revista impresa:

Apellidos, A. A. (Año). Título del artículo. Título de la publicación, vol(núm), pp.-pp.

Artículo en revista electrónica con doi:

Apellidos, A. A; Apellidos, B. B. y Apellidos, C. C. (Año). Título del artículo. Título de la publicación, vol(núm.), pp.-pp. doi: xxxxxxxxxxxx

Artículo en revista electrónica con URL sin doi:

Apellidos, A. A; Apellidos, B. B. y Apellidos, C. C. (Año). Título del artículo. Título de la publicación, vol (núm.), pp.-pp. Recuperado de http://www.

$\underline{\operatorname{Xxxxxx}}$

Artículo de periódico:

Apellidos, A. A. (día, mes y año). Título del artículo. Título del Periódico, pp. $\mathrm{xx}-\mathrm{xx}$.

Artículo de periódico en línea:

Apellidos, A. A. (día, mes y año). Título del artículo. Título del Periódico.

Recuperado de http://www.xxxxxxxx

Tesis:

Apellidos, A. A. (año de publicación). Título de la tesis doctoral o tesis de maestría (tesis doctoral o tesis de maestría inédita). Nombre de la institución: Lugar.

Tesis publicada en línea:

Apellidos, A. A. (año de publicación). Título de la tesis doctoral o tesis de maestría (tesis doctoral o tesis de maestría, Nombre de la institución, Lugar).

Recuperada de http:www.xxxxx

m) Los títulos de los artículos deben ser precisos, acompañados de un resumen, que expresen de manera separada, objetivo; metodología, resultados; limitaciones y o implicaciones, originalidad o valor, y hallazgos y o conclusiones, con una extensión máxima de 150 palabras, equivalente a 10 líneas, en los idiomas español e inglés, con tres a cinco palabras clave. 
n) Las colaboraciones deben ser inéditas y no podrán ser sometidas a la publicación de otra revista o medio de publicación al mismo tiempo, no se podrán publicar más de un artículo por fascículo de cada autor ni más de una vez al año. Nos guiamos por el código de ética COPE committee on publication ethics.

o) Se someterán por el consejo editorial a una revisión interna cuyo fin es corroborar que cuentan con los requisitos para su publicación, posteriormente se sujetará a una evaluación que arrojara un dictamen, en el cual participan dos especialistas externos en forma de nudo ciego, en el área de estudios del artículo, cuyas observaciones se harán del conocimiento del autor para su consideración y correcciones, en caso de que sean aceptadas se enviaran nuevamente a los dictaminadores para que den su veredicto, en caso de no coincidir ambos dictaminadores, se entregará a un árbitro para un tercer dictamen el cual determinará su publicación.

p) Se informará por el consejo editorial el resultado al autor o autores, por medio de correo electrónico. La evaluación se dará durante los 3 meses siguientes a la recepción del trabajo y se publicará durante los 6 meses posteriores.

q) El dictamen arbitral considerará del 1 al 4 -siendo el numero 1 el de menor calificación y el 4 el de mayor calificación-, la relevancia, pertinencia, originalidad, contribuciones al avance de la disciplina, evaluación general del uso y de la actualización de las fuentes utilizadas, consistencia y estructura en la exposición de objetivos y metodología utilizada.

r) Si el dictamen es favorable se someterá la colaboración a la corrección de estilo y se programará la publicación en función de la convocatoria correspondiente de la revista.

s) Cuando un artículo es aceptado se cederán los derechos de autor por escrito a la Universidad de Guadalajara, para ser publicado en forma impresa y electrónica.

t) El autor o autores de los artículos que sean aprobados para su publicación en la Revista Derecho Global, Estudios de Derecho y Justicia, autorizan la publicación de sus trabajos en la RDG en forma física y electrónica, así como a incluirlos en catálogos, base de datos e índices bibliográficos y a inscribir en registro de propiedad intelectual la obra final. Aceptando que el envío de un artículo, constituye estar conforme con la convocatoria y su publicación, así como la cesión de sus derechos a la Universidad de Guadalajara.

\section{4}




\section{Call}

It is summoned to participate through original works that are not being used or manipulated in any other magazines or publishing houses, in Revista Derecho Global. Estudios de Derecho y Justicia (Global Law Magazine. Studies of Law and Justice) which is a publication released every four months in rustic and electronic format of the División de Estudios Jurídicos del Centro Universitario de Ciencias Sociales y Humanidades de la Universidad de Guadajara (CUCSH) with national registration being ISSN 2448-5128 y e-ISSNE 2448-5136. New numbers released on the first day of March, July and November.

The work must be the result of the investigation, whether local, State, National or International in the field of Law, Justice and social sciences related to them.

\section{Rules for the submission of articles}

\section{Rules for the submission of articles}

a) Original and unpublished articles already completed must be sent in Word format to the magazine's mail: derechoglobal@csh.udg.mx

b) The article should not contain the name of the author (s), allowing their identification in the main text.

c) The author (s) will keep an identical copy of the information sent. Verifying its reception with the receipt.

d) The author (s) on a separate sheet, will add the name, as well as a brief biography that do not exceed 150 words of length, describing academic degree and institution where obtained those degrees. Main data from all investigation activities and position held during that investigation, institution, electronic address, postal address, phone number, city and country.

e) The title of the article will be received in Spanish and English.

f) The text must be written in Word format, in Times New Roman, size 12 points, 1.5 interlining, letter size, single-sided, numbered in the upper right margin, 
with a minimum extension of 6,000 and a maximum of 8,000 words that equals 15 to 20 pages, with a normal format of 2.5 centimeters for the lower and upper margin and 3.0 centimeters for the left and right margins.

g) It's necessary to separate the article for a better understanding in subtitles and in case there were in subparagraphs and subsections, aligned to the left.

h) The footnotes should be marked inside text with an Arabic numeral and a footnote, size 10 and line spacing of 1.15, with the APA model, the information corresponding to the content of the source consulted separating each one of the elements of which information is composed with a comma, starting with the surnames of the author, title, publisher, place of impression, pages, etc.

i) In case of internet notes, it is necessary to add, besides the data of the appointment, author and title, the date of consultation. In case of inserting pictures, illustrations, graphs, they will be identified with an ascending number and adding them separately in file preferably Excel or Word and indicating in the general text the place of each element.

j) When fragments quoted in other languages, the author must offer a footnote translating into Spanish and specify that the footnote is a translation. If the translation belongs to a different author from the one that's been subscribed, all recognition shall be given to that author in the biography and the quote.

k) According to APA style, from the exception of the Latin Abrev. et al, the op. cit., $i d$., ibid., neither it's ibidem form shall not be used. So, every time a reference is repeated it must be quoted again.

1) Bibliography will be quoted as:

Books:

Last Name, Year, Title, Place and Editorial.

Book Chapters:

Last name, Year, Chapter Title as A editor and B editor. Book title (PP.xxx$\mathrm{xxx})$. Place : Editorial.

Printed magazine article:

Last name, Year, "Article title", Publication title, volume (number). Pp.-pp.

Article at electronic magazine using doi: 
Last Name A.A, Last name B.B and Last Name C.C (Year). "Article's title”, publication's title, volume (number). Pp.-pp. doi: xxxxxxxxxxx

Article in electronic magazine with URL no doi:

Last name, A.A., Last name, B.B and Last name, C.C (Year) "Article's title". Publication's title, volume (Number, pp.-pp. Retrieved from http://www. $\operatorname{xxxxxx\ldots ...}$

Newspaper article:

Last name, A.A (DAY/MONTH/YEAR) Article's title. Newspaper title, pp.xx-xx.

Online Newspaper article:

Last Name, A.A (DAY/MONTH/YEAR) . “Article's title”. Newspaper's title. Recovered from http://www.xxxxxx....

Thesis:

Last Name, A.A. (Year of publication). Unpublished Doctorate thesis title or Master's thesis. Institutional bodies' name: Place.

Online Published Thesis:

Last Name, A.A (Year of publication). Unpublished Doctorate thesis title or Master's thesis. Recovered from http://www.xxxxxx....

m) The articles must be precise, with an abstract attached to it. They must express objectively and separately the following: Methodology, results; limitations and/or implications, originality and/or value, findings and/or conclusions, with a 150 words of extends, equivalent to 10 lines, whether in Spanish or English, using three to five main words.

n) All collaborations must be unpublished and they cannot be subjected to other magazines or any other publishing media at the same time as our magazine. An author's article cannot be published twice in the same number of the magazine or the same year.

o) It will be subjected by the editorial counsel to an intern review for the purpose of the magazine's requirements corroboration for its publication. Afterwards, it will be subjected to a two external specialist's evaluation as a blind junction at the article's field of studies. Such observations will be of the author's knowledge 
for his/ her consideration and emendations just in case these where previously accepted. The article will be returned to the experts for its evaluation. If the experts don't reach an agreement, a referee will be appointed to decide the article's admittance.

p) The author (s) will be notified of their work's review during the following three months after the article's admittance, which will be published in case of favorable results during the next six months.

q) The expert's report will consider the following values: 1 to 5 relevance, originality, contributions on the field, consistency and the objective's exposition as well as methodology used.

r) If the results are favorable, the article will be subjected to style correction and it's publishing date will be programmed according to this magazine's rules.

s) When an article is accepted, copyrights shall be granted by the Universidad de Guadalajara, to be electronically published and physically printed, and to be storage in database and bibliographically indexed as well. Also, it will be registered as intellectual property.

t) The author (s) accept the magazine's calling rules before sending the article. 


\section{Boletín de suscripción}

Suscripción anual (3 números): \$1,200.00 + gastos de envío.

Precio por Número: $\$ 400.00+$ gastos de envío.

Modo de pago: Depósito bancario

Número de Referencia: 90000005315

Convenio: CIE528313

Banco: Bancomer

Procedimiento de pago:

1.- Hacer el depósito en Bancomer

2.- Escanear ficha de depósito y enviar al correo con los datos siguientes al correo: derechoglobal@csh.udg.mx

Datos de suscripción anual:

\begin{tabular}{|c|c|}
\hline Fecha: & \\
\hline Nombre de quie & \\
\hline Institución a la & \\
\hline Periodo: & \\
\hline Dirección & País: \\
\hline Código postal: & Estado: \\
\hline Teléfono: & Ciudad: \\
\hline
\end{tabular}

Datos de compra individual

Fecha:

Nombre de quien suscribe:

Institución a la que suscribe

\begin{tabular}{|l|l|}
\hline Periodo: & Número \\
\hline Dirección & País: \\
\hline Código postal: & Estado: \\
\hline Teléfono: & Ciudad: \\
\hline Correo electrónico: & \\
\hline
\end{tabular}

